\title{
Occupational exposure to animals and antibodies against Pasteurella multocida
}

\author{
D CHOUdAT, ${ }^{1}$ C LE GOFF,${ }^{2}$ B DELEMOTTE, ${ }^{3}$ G PAUL, ${ }^{4}$ V MADY,${ }^{2} \mathrm{~J} \mathrm{FAGES,}^{3}$ \\ F CONSO
}

From the Département de Médecine du travail, ${ }^{1}$ Faculté Cochin-Port-Royal, 75674 Paris Cedex 14; Institut d'Elevage et de Médecine Vétérinaire des Pays Tropicaux, ${ }^{2} 94700$ Maisons-Alfort; Mutualité Sociale Agricole, ${ }^{3}$ 75008 Paris; and Service de Bactériologie, ${ }^{4}$ Hôpital Cochin, 75674 Paris Cedex 14, France

\begin{abstract}
The relation between occupational exposure to cattle and prevalence of antibodies against Pasteurella multocida was evaluated in 680 workers. Three groups of exposed workers in abattoirs and slaughterhouses (S), in industrial breeding (I), and in traditional breeding (T) were compared with control workers not exposed to cattle or chicken (C). The prevalence of antibodies against capsular antigen $\mathrm{A}$ determined by indirect haemagglutination was significantly higher in the exposed groups ( $\mathrm{S}: 26.2 \% ; \mathrm{I}: 29.0 \% ; \mathrm{T}: 32 \cdot 1 \%)$ than in the control group (C: $14.0 \%)$. The prevalence of antibodies against capsular antigen $\mathrm{D}$ did not differ significantly between the groups. The prevalence of antibodies against one or more somatic antigens $1,2,3,7,8$, or 9 was higher in the exposed groups with a significant difference only for group $T$ versus group $C(p<0.05)$. There was also a significant relation between antibodies against capsular antigen $\mathrm{A}$ and the contacts with pets. This high prevalence of antibodies against $\boldsymbol{P}$ multocida suggests that the infection is frequently subclinical and not only a disease associated with pets but also an occupationally related infection.
\end{abstract}

Pasteurella multocida is a Gram-negative coccobacillus commonly found in the oral and nasal cavities of many animals. Human infections typically follow animal bites or scratches but in some cases the infection is not confined to soft tissues. ${ }^{1}$

Proof of $\boldsymbol{P}$ multocida as the cause of infection requires culture of the organism but isolation of the bacteria may be difficult. Serological diagnosis is routinely used by veterinarians and has been assayed in a few cases of proved infection in man. High titres of antibodies against $P$ multocida are found in recent infections. ${ }^{23}$ An epidemiological survey in an urban population of 245 subjects showed a high prevalence of antibodies against $P$ multocida $(16 \%)$ with a relation with pets ${ }^{4}$; no seroepidemiological study was performed among workers exposed to animals.

The purpose of the present study was to determine the relation between occupational exposure to cattle and the prevalence of antibodies against $\boldsymbol{P}$ multocida.

Accepted 10 November 1986

\section{Materials and methods}

STUDY POPULATION

Between January and June 1985, 680 workers had a blood sample taken and were given a questionnaire. All resided and worked in the same geographical area in four districts in west France. We compared 157 control subjects with 523 subjects occupationally exposed to animals: four types of workers were selected according to their exposure to cattle or chickens:

Group $S$-Workers in abattoirs and in chicken slaughtering plants.

Group I-Farmers in industrial breeding.

Group $T$-Farmers in traditional breeding.

Group C-Control subjects not exposed to cattle or chickens.

\section{QUESTIONNAIRE}

Each subject completed the questionnaire. It contained questions on individual characteristics such as age, race, type and duration of work, contacts with pets or cattle, and recent bites or scratches. 


\section{SEROLOGICAL TESTS}

The strains used for the tests were classified as the capsular serotypes defined by Carter $^{5-7}$ and as the somatic serotypes defined by Namioka. ${ }^{8-10}$

Purified capsular antigens A and D were obtained by the technique of Carter ${ }^{6}$ or of Westphal et al ${ }^{11}$ from 18 hour cultures of $P$ multocida. The pellets were resuspended in phosphate buffered saline (PBS) and heated at $56^{\circ} \mathrm{C}$ for 30 minutes. After centrifugation each supernatant was treated by hyaluronidase $(50 \mathrm{U})$ for two hours at $37^{\circ} \mathrm{C}$. Then the bacterial extract was fixed on sheep red blood cells. One millilitre of the antigen solution was incubated with $0.1 \mathrm{ml}$ of sheep red blood cells in PBS for two hours at $37^{\circ} \mathrm{C}$. The sensitised blood cells were centrifuged, washed, and diluted to $1 \%$ in PBS.

One millilitre of decomplemented serum of each patient was mixed with $0.1 \mathrm{ml}$ of sheep red blood cells. After two hours at $37^{\circ} \mathrm{C}$ or 12 hours at $4^{\circ} \mathrm{C}$, the cells were removed by centrifugation and the adsorbed serum was diluted by twofold serial dilutions in ten tubes $(0.4 \mathrm{ml}$ per tube) or dispensed into a microtitre plate $(0.05 \mathrm{ml}$ per well). The same volume of sensitised red blood cells was added to the tubes or to the wells. The rack of tubes was shaken and then kept at room temperature for two hours, at which time a reading was taken.

The somatic antigens were obtained by the technique of Namioka and Murata ${ }^{8}$ or by a technique derived from Carter ${ }^{6}$ : the 18 hour growth from a tryptose serum agar plate was removed and collected by centrifugation. The bacteria were suspended in PBS and treated by hyaluronidase $(50 \mathrm{U})$ for two hours at $37^{\circ} \mathrm{C}$. After washing, they were treated by sodium dodecyl sulphate $(0.02 \%)$ for 30 minutes at room temperature. The bacteria were washed three times after which sufficient PBS (formol $0.3 \%$ ) was added to obtain an opacity equivalent to tube 50 of Brown. On a glass plate, $50 \mu$ l of each suspension of somatic antigen and $50 \mu \mathrm{l}$ of the serum were mixed and mechanically shaken for two minutes. To facilitate reading, the reactions were observed using a lens. The sera were examined without dilution. If the reac- tion was positive with pure serum, twofold dilution $\overline{\bar{\Omega}}$ from $1 / 5$ were tested.

Appropriate controls included positive serum fron a known hyperimmunised rabbit and negative serum. which served as a reference standard for each batch of test serum.

\section{STATISTICAL ANALYSIS}

Group C was compared with the three expose $\bar{\phi}$ groups to take into account contacts with pets and

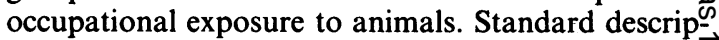
tive statistics were used to represent response as a fre. quency distribution and to calculate group means and variances. Chi square tests were used with $2 \times 2$ con tingency tables to determine whether the relation shown between the variables were statisticall\$ significant. Comparisons of quantitative data wer made using the standard unpaired $t$ test.

\section{Results}

Table 1 shows the characteristics of the populations? The comparison between the control group (C) and the groups occupationally exposed to animals showe a higher frequency of pets in group I $\left(\chi^{2}=6.45\right.$ p $\mathrm{p}<0.02)$ and in group $\mathrm{T}\left(\chi^{2}=44.8, \mathrm{p}<0.0001\right)$ and of recent bite or scratches in group $I\left(\chi^{2}=22 \cdot 3 \frac{\mathrm{N}}{\mathrm{T}}\right.$ $\mathrm{p}<0.0001$ ).

Among the whole population, antibodies agaifiss capsular antigen $A$ were found in $26.3 \%$ with ti from $1 / 20$ to $1 / 640$ and against capsular antigen $6.7 \%$ with titres from $1 / 20$ to $1 / 80$. The antibodies against capsular antigen $D$ were observed only in as sociation with antibodies against capsular antigen $A$ 응

The prevalence of antibodies against somatie antigens $1,2,3,7,8$, and 9 was $8.9 \%$ of the whol $\vec{E}$ population with titres from pure serum to $1 / 80$.

There was a significant relation between the pres? ence of antibodies against capsular antigens and the presence of antibodies against somatic antigen $\left(\chi^{2}=12.55, \mathrm{p}<0.0005\right)$ : the presence of one type of antibody increased the frequency of observing the other type in association (table 2).

Table 1 Characteristics of control group (C) and three exposed groups: $S$ workers in slaughterhouse, I intensive breeding, T traditional breeding

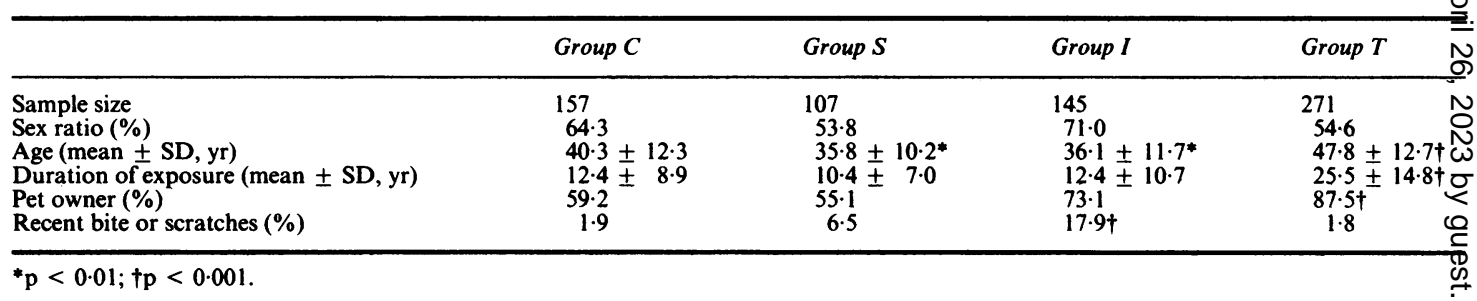


Table 2 Significant relation between antibodies against capsular antigen $A$ and antibodies against somatic antigens $\left(\chi^{2}: 12 \cdot 55, p<0.0005\right)$

\begin{tabular}{lccc}
\hline & \multicolumn{2}{c}{ Antibodies against capsular antigen $A$} \\
\cline { 2 - 3 } & \multicolumn{1}{c}{ Present } & Absent & Total \\
\hline & & \\
Antibodies against somatic antigens: & 33 & 61 \\
Present & 28 & 468 & 619 \\
Absent & 151 & 501 & 680 \\
& 179 & & \\
\hline
\end{tabular}

The distribution of the titres of the different types of antibodies against $\boldsymbol{P}$ multocida antigens according to the groups are shown in tables 3,4 , and 5 . The presence of antibodies against capsular antigen A differed significantly between groups (table 3): the prevalence was $14.0 \%$ in the control group, $26.2 \%$ in group $S(p<0.02), 29.0 \%$ in group I $(p<0.01)$, and $32.1 \%$ in group $T(p<0.001)$. Significant relations between group $C$ and the exposed groups were not found for antibodies against capsular antigen D (table 4), or for each antibody against somatic antigens $1,2,3,7,8$, or 9 (table 5). The prevalence of antibodies against one or more somatic antigen was higher in the exposed groups (figure), however, with a significant difference only for group $\mathrm{T}$ versus group $\mathrm{C}$ $(\mathrm{p}<0.05)$.

In the whole population the prevalence of antibodies against capsular antigens $A$ increased significantly with contact with pets and cattle (table 6 ). The prevalence of antibodies against somatic antigens increased only for the subgroup with simultaneous contact with pets and cattle. The mean age and the mean duration of exposure were higher for the subjects with antibodies against capsular antigens than for the subjects without antibodies (table 7).

Table 3 Distribution of titres of antibodies against capsular antigen $A$ by: $C$ control, $S$ slaughterhouse, $I$ intensive breeding, $T$ traditional breeding

\begin{tabular}{|c|c|c|c|c|c|c|c|}
\hline \multirow{2}{*}{$\begin{array}{l}\text { Type } \\
\text { of } \\
\text { exposure }\end{array}$} & \multicolumn{7}{|c|}{ Titres of antibodies against capsular antigen $A$} \\
\hline & 0 & $1 / 20$ & $1 / 40$ & $1 / 80$ & $1 / 160$ & $1 / 320$ & $1 / 640$ \\
\hline $\begin{array}{c}\text { Group C: } \\
\text { No } \\
\%\end{array}$ & $\begin{array}{l}135 \\
86.0\end{array}$ & $\begin{array}{c}14 \\
8.9\end{array}$ & $\begin{array}{l}6 \\
3 \cdot 8\end{array}$ & $\begin{array}{l}1 \\
0.6\end{array}$ & $\begin{array}{l}1 \\
0.6\end{array}$ & & \\
\hline $\begin{array}{c}\text { Group S: } \\
\text { No } \\
\% \\
\text { Groun I. }\end{array}$ & $\begin{array}{l}79 \\
73 \cdot 8\end{array}$ & $\frac{14}{13 \cdot 1}$ & $\begin{array}{l}9 \\
8 \cdot 4\end{array}$ & $\begin{array}{l}4 \\
3 \cdot 7\end{array}$ & $\begin{array}{l}1 \\
0.9\end{array}$ & & \\
\hline $\begin{array}{l}\text { Group I: } \\
\text { No } \\
\%\end{array}$ & $\begin{array}{l}103 \\
71 \cdot 0\end{array}$ & $\begin{array}{l}17 \\
11 \cdot 7\end{array}$ & $\begin{array}{l}17 \\
11 \cdot 7\end{array}$ & $\begin{array}{l}3 \\
2 \cdot 1\end{array}$ & $\begin{array}{l}1 \\
0.7\end{array}$ & $\begin{array}{l}3 \\
2 \cdot 1\end{array}$ & $\begin{array}{l}1 \\
0 \cdot 7\end{array}$ \\
\hline $\begin{array}{l}\text { Group 1: } \\
\text { No } \\
\%\end{array}$ & $\begin{array}{c}184 \\
67 \cdot 9\end{array}$ & $\begin{array}{l}48 \\
17 \cdot 7\end{array}$ & $\begin{array}{l}23 \\
8 \cdot 5\end{array}$ & $\begin{array}{l}7 \\
2 \cdot 6\end{array}$ & $\begin{array}{l}6 \\
2 \cdot 2\end{array}$ & $\begin{array}{l}3 \\
1 \cdot 1\end{array}$ & \\
\hline
\end{tabular}

Table 4 Distribution of titres of antibodies against capsular antigen $D$ by group

\begin{tabular}{|c|c|c|c|c|}
\hline \multirow{2}{*}{$\begin{array}{l}\text { Type } \\
\text { of } \\
\text { exposure }\end{array}$} & \multicolumn{4}{|c|}{ Titres of antibodies against capsular antigen D } \\
\hline & 0 & $1 / 20$ & $I / 40$ & $1 / 80$ \\
\hline $\begin{array}{c}\text { Group C: } \\
\text { No } \\
\%\end{array}$ & $\begin{array}{c}145 \\
92.4\end{array}$ & $\begin{array}{l}6 \\
3 \cdot 8\end{array}$ & $\begin{array}{l}5 \\
3 \cdot 2\end{array}$ & $\begin{array}{l}1 \\
0.6\end{array}$ \\
\hline $\begin{array}{c}\text { Group S: } \\
\text { No } \\
\% \\
\text { Groun I: }\end{array}$ & $\begin{array}{l}94 \\
87.9\end{array}$ & $\begin{array}{l}10 \\
9 \cdot 3\end{array}$ & $\begin{array}{l}3 \\
2 \cdot 8\end{array}$ & \\
\hline $\begin{array}{l}\text { No } \\
\% \\
\text { Groun T. }\end{array}$ & $\begin{array}{l}135 \\
93 \cdot 1\end{array}$ & $\begin{array}{l}8 \\
5 \cdot 5\end{array}$ & $\begin{array}{l}2 \\
1.4\end{array}$ & \\
\hline $\begin{array}{l}\text { No } \\
\%\end{array}$ & $\begin{array}{c}260 \\
95.9\end{array}$ & $\begin{array}{l}9 \\
3 \cdot 3\end{array}$ & $\begin{array}{l}1 \\
0.4\end{array}$ & $\begin{array}{l}1 \\
0.4\end{array}$ \\
\hline
\end{tabular}

\section{Discussion}

A particularly noteworthy observation was that the prevalence of healthy subjects with antibodies against capsular antigen A of $P$ multocida is high, even in the control group (C:14\%); this prevalence is similar to that previously observed in an urban population $(16 \%) .{ }^{4}$ The prevalence of antibodies against capsular antigen $\mathbf{A}$ is higher in occupationally exposed groups (S:26.2\%; I : 29.0\%; T : 32.1\%) (table 3). This high prevalence of antibodies against $P$ multocida may reflect underdiagnosed cases of infection or asymptomatic immunisation.

The prevalence of both human brucellosis and

Table 5 Distribution of titres of antibodies against somatic antigens $1,2,3,7,8$, and 9 by group

\begin{tabular}{|c|c|c|c|c|c|c|c|c|}
\hline \multirow{2}{*}{$\begin{array}{l}\text { Somatic } \\
\text { antigen }\end{array}$} & \multirow{2}{*}{$\begin{array}{l}\text { Type of } \\
\text { exposure }\end{array}$} & \multicolumn{7}{|c|}{$\begin{array}{l}\text { Titres of antibodies against somatic } \\
\text { antigens }\end{array}$} \\
\hline & & 0 & $1 / 1$ & $1 / 5$ & $1 / 10$ & $1 / 20$ & $1 / 40$ & $1 / 80$ \\
\hline \multirow[t]{4}{*}{$0: 1$} & C & 157 & & & & & & \\
\hline & $\mathbf{S}$ & 106 & & 1 & & & & \\
\hline & I & 143 & 1 & i & & & & \\
\hline & $\mathrm{T}$ & 267 & $i$ & $i$ & 2 & & & \\
\hline \multirow[t]{3}{*}{$0: 2$} & C & 154 & 3 & & & & & \\
\hline & $\begin{array}{l}\mathbf{S} \\
\mathbf{I}\end{array}$ & $\begin{array}{l}105 \\
143\end{array}$ & $\begin{array}{l}1 \\
2\end{array}$ & 1 & & & & \\
\hline & $\mathbf{T}$ & 267 & 3 & & 1 & & & \\
\hline \multirow[t]{3}{*}{$0: 3$} & C & 155 & 1 & 1 & & & & \\
\hline & $\begin{array}{l}\text { S } \\
\mathbf{I}\end{array}$ & $\begin{array}{l}107 \\
144\end{array}$ & & 1 & & & & \\
\hline & $\mathrm{T}$ & 268 & 2 & & 1 & & & \\
\hline \multirow[t]{4}{*}{$0: 7$} & C & 155 & 1 & & i & & & \\
\hline & $\mathbf{S}$ & 102 & 2 & 2 & 1 & & & \\
\hline & I & 140 & 2 & 3 & & & & \\
\hline & $T$ & 249 & 10 & 8 & 2 & 1 & & 1 \\
\hline \multirow[t]{3}{*}{$0: 8$} & C & 155 & 1 & 1 & & & & \\
\hline & $\mathbf{S}$ & $\begin{array}{l}104 \\
142\end{array}$ & $\begin{array}{l}3 \\
2\end{array}$ & & 1 & & & \\
\hline & $\mathrm{T}$ & 257 & 8 & 3 & 2 & 1 & & \\
\hline \multirow[t]{3}{*}{$0: 9$} & C & 156 & 1 & & & & & \\
\hline & $\mathbf{S}$ & 107 & & & & & & \\
\hline & $\mathrm{T}$ & $\begin{array}{l}143 \\
268\end{array}$ & $\begin{array}{l}1 \\
2\end{array}$ & 1 & & 1 & & \\
\hline
\end{tabular}




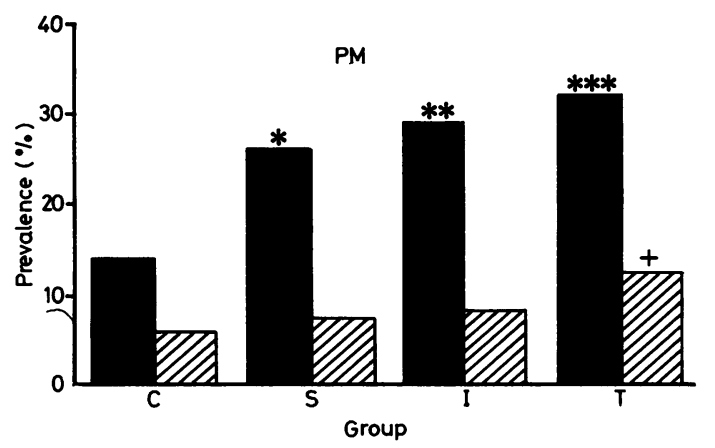

Prevalence of antibodies against capsular antigens (solid columns) and against somatic antigens (shaded columns) by group $\left(+p<0.05 ;{ }^{*} p<0.02 ;^{* *} p<0.01 ;{ }^{* * *} p<0.001\right)$.

pasteurellosis seems similar: in slaughterhouses the frequency of antibodies against Brucella is about $8.8 \%{ }^{12}$ to $24 \%{ }^{13}$ according to the titres and the working conditions.

We have not found a significant relation between a history of recent bites or scratches and the presence of antibodies but the subjects with antibodies had a higher mean duration of exposure than the subjects without antibodies (table 7): the immunological memory is perhaps better than recall explored by questionnaire.

We have studied only capsular antigens $A$ and D because the two others ( $B$ and $E$ ) are not found in
Europe. The higher prevalence of antibodies against $\overline{\bar{z}}$ capsular antigen $A$ than antigen $D$ is explained by the preponderance of this serotype in the animal and human infections. This result supports other findings in an urban population. ${ }^{4}$ The somatic antigens $0: 7$ and $0: 8$ were also the most frequent (table 5).

A few subjects only had titres as high as those found in acute infections in animals or man. ${ }^{3}$ The low titres observed may be declining after infection or they may follow weak antigen stimulation by scratches or mucous carriage.

In conclusion, despite its high prevalence among animals, pasteurellosis is rarely diagnosed in man. This serological survey, however, suggests that the infection is frequently subclinical. The high prevalence of antibodies and the significant relation with contacts with pets, cattle, and chickens suggest that it is not only a disease associated with pets but also an occupationally related infection.

We are grateful to Drs G Benesy, $\mathrm{H}$ Blanchet, M F Demange, and J Y Saillard, mutualité sociale agricole of Laval, Angers, Niort, and Nantes, for carrying out the data. We are also grateful to Drs F Neukirch and T Berriau, Miss D Deschamps, and Mr D Lafon for their help; to Dr J L Kearns for reading this paper; and to Mrs B Najac for preparing the manuscript.

\section{References}

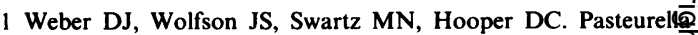
multocida infections: report of 34 cases and review of the

Table 6 Prevalence of antibodies against P multocida antigens and exposure to pets or cattle. The differences were significant between subjects not exposed to animals (first column) and subjects exposed to pets or cattle or both

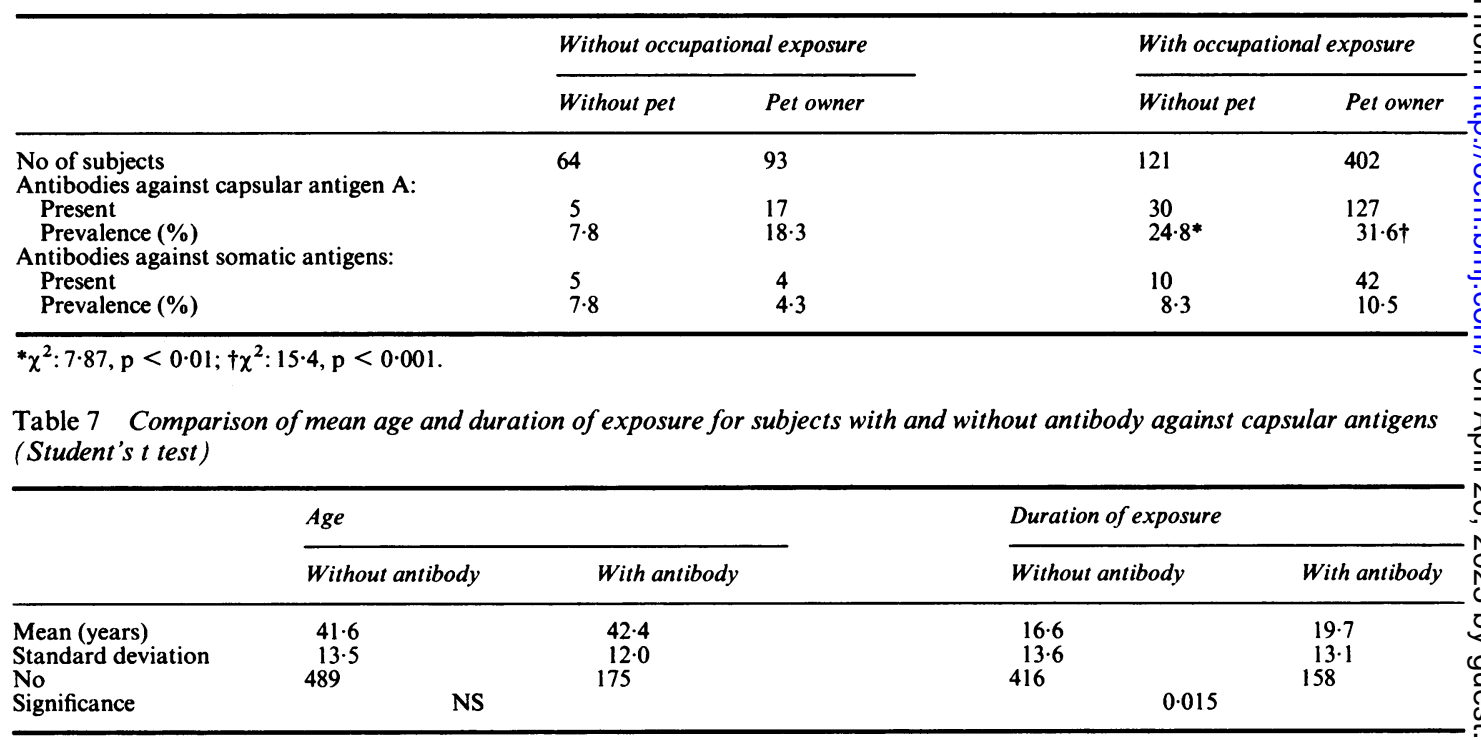


literature. Medicine (Baltimore) 1984;63:133-54.

2 Guillausseau PJ, Paul G, Caquet R, Detilleux M, Laroche C. Evolution inhabituelle d'une pasteurellose humaine après morsure de chat. Nouv Press Med 1976;5:1579-81.

3 Choudat D, Le Goff C, Paul G, Choudat L, Marsac J, Nevot P. Sérodiagnostic des infections respiratoires à Pasteurella multocida. Rev Mal Prespir 1985;2:325.

4 Choudat D, Le Goff C, Paul G, Choudat L, Poggi D, Nevot P, Perreau P. Animaux familiers et prévalence des anticorps anti Pasteurella multocida dans une population urbaine. Médecine et Maladies Infectienses 1986;16:13-7.

5 Carter GR. The type specific capsular antigen of Pasteurella multocida. Canadian Journal of Medical Science 1952;30: 48-53.

6 Carter GR. Studies on Pasteurella multocida. I-a hemagglutination test for the identification of serological types. $\mathrm{Am} \mathrm{J}$ Vet Res 1955;16:481-4.

7 Carter GR. Proposed modification of the serological classification of Pasteurella multocida. Vet Rec 1963;75:1264.
8 Namioka S, Murata M. Serological studies on Pasteurella multocida. II. Characteristics of somatic (O) antigen of the organism. Cornell Vet 1961;51:507-21.

9 Namioka S, Murata M. Serological studies on Pasteurella multocida. III. $\mathrm{O}$ antigenic analysis of cultures isolated from various animals. Cornell Vet 1961;51:522-8.

10 Namioka S, Bruner DU. Serological studies on Pasteurella multocida. IV. Type distribution of the organism on the basis of their capsule and O groups. Cornell Vet 1963;53:41-53.

11 Westphal $O$, Luderitz $O$, Bister $F$. Uber die extrakion von Bakterien mit Phenol/Wasser. Z Naturfors 1952;7b:148.

12 Alleyne BC, Orford RR, Lacey BA, White FMM. Rate of slaughter may increase risk of human brucellosis in a meatpacking plant. J Occup Med 1986;28:445-50.

13 Cantineau A, Curtes JP, David C, Pelle JC, Verger C. La brucellose animale et humaine en llle et Vilaine. XVIIIe Journées nationales de médecine du travail. Rennes: Masson ed, 1984:223-6.

\section{Vancouver style}

All manuscripts submitted to the $\mathrm{Br} J$ Ind $\mathrm{Med}$ should conform to the uniform requirements for manuscripts submitted to biomedical journals (known as the Vancouver style)

The $B r J$ Ind Med, together with many other international biomedical journals, has agreed to accept articles prepared in accordance with the Vancouver style. The style (described in full in $\mathrm{Br}$ Med J, 24 February 1979, p 532) is intended to standardise requirements for authors.

References should be numbered consecutively in the order in which they are first mentioned in the text by Arabic numerals above the line on each occasion the reference is cited (Manson ${ }^{1}$ confirmed other reports $\left.{ }^{2-5} \ldots\right)$. In future references to papers submitted to the $\mathrm{Br} J$ Ind Med should include: the names of all authors if there are six or less or, if there are more, the first three followed by $e t$ al; the title of journal articles or book chapters; the titles of journals abbreviated according to the style of Index Medicus; and the first and final page numbers of the article or chapter.

Examples of common forms of references are:

1 International Steering Committee of Medical Editors. Uniform requirements for manuscripts submitted to biomedical journals. Br Med J 1979;1:532-5.

2 Soter NA, Wasserman SI, Austen KF. Cold urticaria: release into the circulation of histamine and eosino-phil chemotactic factor of anaphylaxis during cold challenge. $N$ Engl J Med 1976;294:687-90.

3 Weinstein L, Swartz MN. Pathogenic properties of invading micro-organisms. In: Sodeman WA Jr, Sodeman WA, eds. Pathologic physiology: mechanisms of disease. Philadelphia: W B Saunders, 1974:457-72. 